doi: 10.31211/interacoes.n34.2018.a6

\title{
Utilization of Digital Literacy in Retirement Planning Among Ghanaian Formal and Informal Sector Workers
}

\author{
Delali A. Dovie \\ Department of Sociology, University of Ghana - dellsellad@gmail.com
}

\begin{abstract}
The paper investigates formal and informal sector workers' dependence on digital and non-digital literacy sources and their attendant helpfulness in the process of retirement planning, using qualitative and quantitative datasets. The results show that workers use hybridity of digital and non-digital literacy artifacts in obtaining retirement planning information. The users of non-digital literacy can be termed as the socially excluded from digital space use. These are discussed focusing on uses, functioning, capability, and agency. Digital literacy facilitates retirement planning information access through enhanced media and other literacies and associated competencies, skills, and dispositions, while retirement planning offers

opportunities for obtaining the requisite information with implications for social inclusion. A Cramer's V test of 0.705 indicates a strong association between retirement planning information sources and helpfulness. Comparatively, more formal sector workers are exposed to, and/or users of digital artifacts and literacy due to their nature of work and are thus digitally literate with implications for inequality considerations. This may have consequences for increasing disparities in retirement preparation. Intensification of retirement planning may be aided through greater digital literacy in the future hence salvaging the relatively invisible social groups such as informal sector workers in the digital age.
\end{abstract}

Keyword: Workers, retirement planning, information, digital literacy, digital capability

\section{Utilização da Literacia Digital no Planeamento da Reforma nos Trabalhadores nos Sectores Formal e Informal no Gana}

\section{Sumário}

Este artigo investiga, através de um conjunto de dados qualitativos e quantitativos, a dependência dos trabalhadores dos sectores formal e informal das fontes de conhecimento digital e não digital e a sua utilidade nos processos de planeamento da reforma. Os resul- tados mostram que os trabalhadores utilizam o hibridismo de artefactos de aprendizagem digital e não digital na obtenção de informações para o planeamento da reforma. Os utilizadores de conhecimento não digital podem ser designados como socialmente ex-

Acknowledgments: I would like to acknowledge the University of Ghana Staff PhD Research Grant for funding the project. 


\section{Utilization of Digital Literacy in Retirement Planning Among Ghanaian Formal and Informal Sector Workers}

cluídos da utilização do espaço digital. Estes são perspetivados através do enfoque nas utilizações, no funcionamento, na capacidade e na agência. A literacia digital facilita o acesso às informações necessárias para o planeamento da reforma através de media sofisticados e outros conhecimentos e competências associadas, enquanto o planeamento da reforma oferece oportunidades para a obtenção de informações necessárias para a inclusão social. $\mathrm{O}$ teste $\mathrm{V}$ de Cramer de 0,705 indica uma associação forte entre as fontes de informação do planeamento da reforma e a uti- lidade. Comparativamente, os trabalhadores do sector formal estão mais expostos a, e/ou são usuários de artefactos e literacia digital devido à natureza do seu trabalho e assim são mais digitalmente instruídos o que tem implicações em termos de desigualdade.

Isto pode ter consequências no aumento das disparidades na preparação da reforma. A intensificação do planeamento da reforma pode ser auxiliada no futuro através de um maior conhecimento digital, resgatando assim grupos sociais relativamente invisíveis, nomeadamente os trabalhados do sector informal na era digital.

Palavras-chave: Trabalhadores, planeamento da reforma, informação, literacia digital, capacidade digital

\section{INTRODUCTION: RETIREMENT PLANNING DYNAMICS}

Retirement planning relates to the various preparations of workers in anticipation of post-retirement life (Agbobli, 2011). This requires financial knowledge, which facilitates the understanding of key retirement planning concepts, including informed decision-making (Worthington, 2005). Sun et al. (2007, p. 57) asserted that personal retirement planning behavior is a function of access to investment information albeit from digital literacy sources.

Financial education prioritizes advancement and achievement regarding retirement preparations. However, financial illiteracy may stunt people's ability to save and invest for retirement, undermining their well-being in old age (Lusardi \& Mitchell, 2007, p. 14). By definition, financial education is:

the process by which financial consumers/investors improve their understanding of financial products and concepts and, through information, instruction and/or objective advice, develop the skills and confidence to become aware of (financial) risks and opportunities, to make informed choices, to know where to go for help, and to take other effective actions to improve their financial well-being and protection (Messy \& Monticone, 2012, p. 8). 
Similarly, financial literacy is a constellation of awareness, knowledge, skill, attitude, and behavior necessary to make sound financial decisions and ultimately achieve individual financial well-being (Atkinson \& Messy, 2012). Financial literacy finds expression in digital literacy.

Buckingham (2015) argues that technology in itself is neither 'good' nor 'bad' for education. It can be both. However, its value depends on how it is used and the rationale for its usage. If combined with broader changes in pedagogy, it can have a significant positive impact. Yet, the central issues have to do with learning. Technological uses vary, for instance, Selwyn suggests that the opportunities presented by mobile technologies for learning are just as much socially structured as they are individually driven, implying that:

... the likelihood of gaining advantage from digital education is clearly related to the resources that social groups command, therefore pointing towards the role of digital technology in the perpetuation of accumulated advantage and the reproduction of inequalities. (2014, p. 138)

The progress of information communication technology (ICT) into all areas of the economy and society has brought dramatic changes, defining entry into the 21 st century as a digital age. Further, the development of ICT has caused structural changes entailing the issue of their impact on economic growth, the rise in labor productivity, cost reduction and improvement in living standards. There are many outlooks on the benefits of technology for humanity, and the achievements of the digital economy are accompanied by concerns about future prosperity, the ongoing divide of the world and society based on digital capabilities, and threats to prosperity due to the loss of jobs. The growth economy hypothetically predicts that investment in ICT drives economic growth. However, several empirical studies on the impact of ICT have produced mixed results, being partly influenced by reasonably differing research methodologies with a focus on different countries (Urbančíková et al., 2017).

According to Pahl (2014), the 'stuff' of digital literacies is materialized in smartphones, screens, tablets, and other complex digital literacy artifacts that spill into the 'stuff' of everyday life (p. 173). McDougall et al. (2018) have outlined three main research fields that are a conceptual framework and approaches oriented namely digital literacy, the third space, and uses of digital literacy. The first includes work on the relationship between technology and learning, where learning entails identity work 


\section{Utilization of Digital Literacy in Retirement Planning Among Ghanaian Formal and Informal Sector Workers}

and civic engagement; the second provides ways of understanding geographies of activity and the blurred boundaries between these territories; and the third provides a lens through which sense is made of the range of things which people do with digital technology (p. 3). Of these, the uses of digital literacy dimension are of significance in this paper. It is in this context that the connection between Hoggart's (1957) notion of 'uses' and Amartya Sen's (2008) notion of 'functioning' is drawn.

Digital literacy implies acting in new ways on information in digital form and through new organizational forms (Aral et al., 2006; Brynjolfsson \& Brown, 2005). New technology always plays a key role in discovering and determining new skills considered necessary for its enforcement in the economy. The deployment of ICT technologies in all the sectors of the economy culminate in a new situation that demands broad new skills. Computers have long been regarded as a sole concern, requiring advanced new skills. Later, internet diffusion added significant pressure on the use of further internet literacies. Digital literacy is an "ability to understand and to use information from a variety of digital sources," as required by the new digital age (Gilster, 1997). Further, some other authors argue and consider digital literacy as a special kind of mindset or thinking and not only a practical ability to use digital sources effectively. Over the past three decades, several approaches have emerged to classify old and new literacy skills that are needed in the 21 st century among workers.

Comparatively, information literacy is focused on the way in which information is accessed and evaluated (Martin, 2006), accentuating the location and identification, further evaluation, including the use of media. Additionally, Warschauer and Matuchniak (2010) posit that a skill set can be assigned to digital literacy and one of the esteemed skill designs is named 21st-century skills. Presently, digital literacy can be considered as an integrating framework of several forms of literacy and skill-sets (Martin, 2006). The lack of digital literacy is a key factor of low prosperity, even in post-retirement life. Vasudevan et al. (2014) note that:

"literacy practices derive their vitality from curricula and activities that connect to learners' backgrounds, cultures, and communities; that capitalize on the social nature of learning; and that position ... people to experience literacy as purposeful and themselves as skillful and confident makers of meaning". (p. 6)

Hull and Nelson (2009) have pointed out that these encourage the redesign of the activities and the development of new measures more sensitive to the kinds of ex- 
panded literacies evident in participants' interactions' (p. 388). This entails building on learners' existing knowledge and cultural practices and situating literacy learning within a larger motivating activity and/or purpose (McDougall et al., 2018, p. 4). Devising strategies that would provide a focus on "the real effective freedoms people have and their choice among possible bundles of functionings" (Terzi, 2005, p. 450) is in keeping with a focus on both human agency and materiality but also with the 'postdigital', by contributing to new knowledge about how the hybridity of digital and non-digital spaces and ambiguous, contingent and asymmetrical interactions within and across them offer a disjuncture to "the hegemony of the digital" (Apperley et al., 2016, p. 263).

The uses of literacy (Hoggart, 1957) is frequently revisited by teachers, academics/researchers, and cultural commentators to address current issues in education and social mobility. Hoggart's exploration of the uses of literacy among working-class communities in the north of England purported that the 'uses' of literacy were understood as double-edged, on the one hand enabling mobility and on the other as a controlling force. If third spaces enable young people to re-frame their digital skills and dispositions towards playful and creative uses of new literacy for schooled learning, this would be a key 'use' of new literacy practices. In this way, digital literacy practices relating to identity, socio-materiality, representation, agency, and play can be potential 'of use' in education and for social mobility and civic engagement.

Updating' Hoggart's (1957) articulation reflects the dynamics of bringing together the shifting and contested versions of literacies which have emerged out of semiotics and multimodality (Kress, 2003), media education (Buckingham, 2003), the new literacy studies (Street, 2003), and 'transmedia literacies' (Jenkins, 2011), all of which stand in contrast to the view of literacy as a static, narrow and autonomous set of skills. These dynamic literacies include providing opportunities for new modes of self-representation and collaborative meaning-making, collecting digital contents, from the blog to the social media page, from the uploaded snap to the chat and the tweet around those pictures and thoughts; and assemblage, where literacy, media, and technology converge in educational contexts as "the material-discursive-semiotic assemblings that are and could be generated ..." (Comber, 2013, cited in Burnett et al., 2016, p. 240). These dynamic practices are located in enabled, negotiated and contested areas between and across physical and virtual (digitally mediated) interactions, in which meanings are made and shared and new kinds of knowledge, representations and efficacy are generated as the 'new uses' of literacy. As Hoggart (1957) observed, though, uses is a duality in the digital age. 
Other uses encompass the following: educational/academic interventions that range from addressing competency gaps to co-creative, participatory projects seeking to utilize digital literacy for constructivist pedagogic means and more ethnographic work seeking to explore how digital practices integrate with socio-cultural factors and personal narratives (see Livingstone \& Sefton-Green, 2016); economic/ employability interventions aimed at increasing digital literacy competencies for accessing services, benefits, training and $21^{\text {st }}$ century workplace practices, whilst civic engagement/societal well-being initiatives attempt to use digital literacy as a conduit for participation in democracy or accessing public services (e.g., Nuffield Trust, 2016).

The theoretical underpinning of this paper finds expression in Atchley's (2000) stages of retirement theory. The theory espouses the following phases: the pre-retirement, honeymoon, immediate routine, rest, disengagement, reorientation, retirement routine and termination of retirement. Of key importance to the phenomenon of retirement planning and therefore this paper is the pre-retirement planning phase. This phase is constituted by pre-retirement education (PRE) which relates to financial planning; health and lifestyle topics; legal issues; housing information; work after retirement; fitness and relationships. More importantly, digital and non-digital literacy sources are the core constituents of PRE, even in the retirement planning process.

In recent years, westernization, urbanization, education and social mobility have put a strain on the extended family system such that people have shifted their attention from the extended family system towards self-preparedness to life in old age. "Poor (financial) planning for retirement is reported to be a major problem among formal and informal sector workers and may compound the overdependence documented among elderly individuals" (de-Graft Aikins et al., 2016, p. 176). The study explores formal and informal sector workers' sources of retirement planning information and their attendant helpfulness in the retirement planning process.

\section{METHOD AND DATA ANALYSIS}

Ghana has diverse ethnic, linguistic, and religious groups. Ghana is a member of various social, political, and economic organizations namely the Non-Aligned Movement, the African Union, the Economic Community of West African States, Group of 24 and the Commonwealth of Nations. Tema is a typical major Ghanaian city that 
is privy to and epitomizes an urban setting, which articulates the deepened prongs of workers' retirement preparations and contemporary issues.

The explanatory sequential mixed methods strategy was employed in this study. Using a three-phase approach, the study gathered both qualitative and quantitative data. The first phase constituted the initial qualitative stage that obtained data from state-designated institutions such as the National Pensions Regulatory Authority (NPRA), the Social Security and National Insurance Trust (SSNIT) and SSNIT Informal Sector Fund (SSNIT ISF). These have the mandate to manage and address workers' pension contribution related issues. These organizations and their requisite officials were purposively selected. Key informant interviews were used to elicit important data from the officials. In all, seven key informant interviews were conducted. During the interviews, the voices were audiotaped, before which the consent of the participants was sought. Notes were written as a backup to the voice recordings. The key informant interviews took the form of face-to-face and one-on-one in-depth discussions.

The second phase ascertained workers' general views on retirement planning and the prerequisite information. Number of years of education and the nature of the job were the co-variables that were of significance to the issues articulated in this article. In consequence, the quantitative data explored the following hypotheses: 1 . Number of years of education will have a significant effect on retirement planning information access; 2 . There is an association between retirement planning information sources and usefulness. Following the guidelines of Creswell and Plano Clark (2007), thematic analysis of the data collected in phase I was utilized in informing the development of the survey instrument for this phase. A multi-stage clustered sampling technique was used to select a sample of 442 workers aged 18-59 years utilizing the formula by Moore and McCabe (1993). An anticipated non-response was built into the survey design. Further, organizations were first stratified into formal and informal sectors, after which they were then clustered into manufacturing, administrative and service units. Out of these, the administrative and service units were randomly selected. From these, individual workers were also randomly selected. In which case, the total population of Tema according to Ghana Statistical Service (2014) is 292,772, out of which 135, 640 are employed, and it was from this that the sample for the study was selected.

A questionnaire was used in data collection in this phase. The administration of which took the form of face-to-face interviews to eliminate the situation of unre- 


\section{Utilization of Digital Literacy in Retirement Planning \\ Among Ghanaian Formal and Informal Sector Workers}

turned questionnaires. To facilitate this, interview appointments were booked severally. The study set out to investigate the association between number of years of education and retirement planning information access, and retirement planning information and the related usefulness.

The third phase sought to understand the lived experiences of workers' retirement preparation information acquisition and/or access. During this phase, 20 respondents who had participated in the second phase also took part in follow up interviews with the purpose of obtaining an explanation for issues raised in phase II. In-depth interviews were used in the gathering of data. Interviews were conducted for a period ranging between 60 and 90 minutes. Before which permission, to tape record discussions including informed consent were sought.

The interview guides and questionnaire were piloted to ensure accuracy in understanding, fluency, and proper wording of questions. The face-to-face interviews were conducted in both English language and Ghanaian languages, namely Ga, Ewe, and Twi.

The key informant and in-depth interviews were preliminarily analyzed as they were being collected based on which modifications were made in the sampling strategy before the next series of interviews to ensure gaps were ascertained and rectified. This act preserved the multivocality and complexity of lived experiences while maintaining focus on the study's theme. The qualitative data analysis process was undertaken following Bryman's (2008) analysis strategies. A combination of the following analytic strategies was employed in this study. First, analytic induction, which was related to reaching general explanations, was used. Second, thematic analysis was undertaken in relation to the examination of theoretical themes or hypotheses of research through studying particular cases. Finally, the narrative analysis was used to search for new issues from the stories told by the research participants about their lives.

The analysis process was aided by the application of the framework method in which matrix-based comparisons such as comparative tables were undertaken. The framework table offered a detailed analysis of the data within a particular theme. This, therefore, provided a clearer and deeper understanding of key themes within the context of the study. The efficiency of the thematic analysis carried out was ensured following a variety of principles in the course of data processing. These include repetition in search of issues that are commonly repeated by interviewees, non-repetition in search of issues that were rarely mentioned by the interviewees; similarity 
and difference in a search of similar and different responses among interviewees on a given theme such as digital and non-digital resource patronage; transitions in search for issues that link themes and sub-themes together. Theory linkage in search for linkage or connections to scientific concepts or theory for the outcome of research findings. These were undertaken to ensure the pursuance of the relationship between categories and themes of data seeking to increase the understanding of the phenomenon.

Further, Nvivo Software was used to facilitate text coding and to retrieve coded texts as well as interpret the data. The analytical process articulated by Bazeley and Jackson (2014) was followed, using five distinct steps. A project was created which comprised all the documents, coding data and related information that assisted in the process of data analysis as well as saving the NVivo project. The transcribed audiorecorded interview files were named respectively. Qualitative data files which entailed the preparation of documents for import, following which the necessary documents that were intended to be analyzed were then imported. Additionally, notes were engaged as a place in NVivo for references to code text.

A chunk of data in a project document under a particular node was taken through the highlight of the critical text using the mouse and pulling the highlighted texts to the identified node using the coder. This entailed finding obvious themes as well as auto-coding. Subsequently, multiple codes were assigned to the same chunk of the texts including going through the same process. The codes formed a pattern. The passages of texts were compared for ways in which they were similar and different. The emergent concepts, for example, were all retirement planning information responses. Others were the dimension of the use of accessibility of digital and non-digital artifacts, a host of others. The final step pertained to going further which encompassed the following: the start of the analysis, going further with concepts, categories, and themes including narrative and discourse. Memos were used to tell the story of the research by adding descriptions. The knowledge developed from the data was reported.

The outcomes of these activities were recorded in discussion memos. These strategies were integrated into the process of learning from the data. A thematic multicase analysis was employed, the comparative focus of which was on individual cases including the preservation of their uniqueness. Miles and Huberman (1994) have succinctly expressed the goals of this type of analysis as follows: 


\section{Utilization of Digital Literacy in Retirement Planning \\ Among Ghanaian Formal and Informal Sector Workers}

One aim of studying multiple cases is to increase generalizability, reassuring yourself that the events and processes in one well-described setting are not wholly idiosyncratic. At a deeper level, the aim is to see processes and outcomes across many cases, to understand how they are qualified by local conditions, and thus to develop more sophisticated descriptions and more powerful explanations.

Further counts of a theme within the unstructured text were used as a proxy indicator of the significance of that theme for qualitative analysis. The themes appeared as major findings and were used to create headings in the results section of the paper. The interrelation between themes involved the use of narrative passage to convey the findings of the analysis. The themes were interconnected into a storyline. From these explorations, the researcher sought to understand how people construct meanings and actions, as preparations for understanding why people act the way they do (Charmaz, 2006). The final step entailed the selection, filtering and viewing of the predefined report for the study. All names used for research informants and interviewees are pseudonyms.

The quantitative data gathered were analyzed using the Statistical Package for Social Science Software (SPSS) version 20.0, using frequencies, percentages, and bivariate analysis. The Pearson Chi-square and Cramer's V test were used in the study as the standard to assess the relationship between the degree of relatedness and unrelatedness. The usage of multi-stage sampling approach means that the results are statistically representative. Thus, generalizability is permissible to the general population.

\section{RESULTS: SOURCES OF RETIREMENT PLANNING INFORMATION}

The study population consisted of 213 males (48.2\%) and 229 females (51.8\%) aged between 18-59 years. Most of the respondents had some level of education and were constituted by the formal sector $(221,50 \%)$ and informal sector workers (221, $50 \%$ ) (Table 1). Overall, the highest educational level attained by a near majority of the respondents (46.4\%) was tertiary education. 
Table 1 - Respondent demographics

\begin{tabular}{cccc}
\hline Variables & Characteristics & Frequency & Percent\% \\
\hline \multirow{2}{*}{ Age } & $18-24$ & 21 & 4.8 \\
& $25-29$ & 42 & 9.5 \\
& $30-34$ & 81 & 18.3 \\
& $35-39$ & 58 & 13.1 \\
& $40-44$ & 67 & 15.2 \\
& $45-49$ & 59 & 13.3 \\
Gender & $50-54$ & 54 & 12.2 \\
& $55-59$ & 60 & 13.6 \\
Educational & Male & 213 & 48.2 \\
level & Female & 229 & 51.8 \\
& No-formal education & 24 & 5.4 \\
Sector of & Pre-tertiary education & 212 & 48.0 \\
work & Tertiary & 206 & 46.4 \\
& Formal & 221 & 50 \\
\hline
\end{tabular}

The sources of retirement planning information can be categorized into two, namely digital and non-digital sources of retirement planning information at the institutional level, and digital and non-digital sources of retirement planning information at the individual level.

Digital and non-digital sources of retirement planning information at the institutional level

The informational functions consist of financial education provided to a worker on entering an organization based on securing gainful employment. It can also be undertaken in the course of working life by way of provision of guidance. The results show that these functions are performed by NPRA, SSNIT including SSNIT ISF (See Table 2) at the large-scale level in relation to the functionality, operationalization, and benefits 
of the new three-tier pension system and/or scheme. At the small-scale level, indeed almost all organizations provide their employees with 'pep-talks' of one form or the other regarding retirement preparation.

It is required of these institutions to sensitize all workers including the general public about the operationalization and functions of the national pension system as a whole as well as the respective Tier constituents and benefits. This is indeed essential because there have been slight changes made to the pension system compared to that under the regulation of SSNIT namely the three core tiers and their benefits. Hence, the need to educate the general public. This singular function is performed differently by all the different institutions involved such as the number of times sensitization is undertaken, the modus operandi within the context of financial information availability and/or constraints. The key informant interviews revealed that all pension service-providing institutions systematically hold financial information sections.

Public education is supposed to be a two-way affair between responsible institutions and workers, which presupposes that just as these institutions must undertake public education; workers should in turn also seek after knowledge and aim higher. Hence the statement that "and then the worker must also seek knowledge. You yourself you must seek knowledge and then the worker must also not be content with the position that he is occupying" (Official 1).

Table 2 - Institutional dynamics of retirement planning information dissemination

\begin{tabular}{cclc}
\hline Function & Institution & \multicolumn{1}{c}{ Strategic tools } & No. of times \\
\hline $\begin{array}{c}\text { Financial } \\
\text { education }\end{array}$ & NPRA & Regional tours & - \\
& & Radio & 24 \\
& \multirow{2}{*}{ SSNIT } & Face-to-face outreach programs & - \\
& & Face-to-face outreach programs & 260,764 \\
& & Media Forum & 3 \\
& & Seminars & - \\
& & Brochures & - \\
& & Leaflets & - \\
& & Television & 4 \\
\hline
\end{tabular}


Sensitizing the public particularly workers on the operationalization, functionality, and benefits of the new pension system offers individuals and/or workers retirement planning opportunities. This may facilitate preparation adequately and effectively towards retirement. This implies that workers may not be entirely and/or adequately knowledgeable about the pension system, although they have been sensitized under the auspices of PNDC Law 247 especially those who were already employed before the institution of Act 766. The important institutions such as the NPRA, consultants, Trustees, among others undertake sensitization programs collaboratively and on a continuous basis. This, in turn, tends to facilitate planning adequately and effectively towards retirement as earlier mentioned. Presently, sensitization programs are undertaken by institutions, e.g., SSNIT on their specific mandates to provide awareness of a general overview of the national pension system.

The informational messages that emerge from public education campaigns come in two forms namely worker and employer-oriented messages. The worker-oriented messages focus on providing workers with insights into updating their recurrent personal records, how to ensure they receive prompt payments. These and others are depicted in the following quotes:

We do education on SSNIT. But sometimes, we trespass and talk more elaborately. We educate them on how to receive their payments promptly, how they can update their current information that's all. (Official 2).

In fact, very serious public education work on the three-tier pension scheme started in 2012 when the authority was able to recruit staff. But a lot of education was also done by the pensions' commission, those who came with the new pension scheme (Official 3).

The employer-oriented messages concentrate on encouraging employers to safeguard the interest of their employees regarding the deduction and onward payment of pension contributions on behalf of the latter promptly, which eventually goes a long way to protect their future - symbolized by post-retirement life.

It is worth reiterating the fact that sources of retirement planning information traverse digital (television, radio, media) and non-digital divides (regional tours, workshops, outreach programs) with SSNIT having the highest number per year features of 260,764 . The sensitization programs are undertaken using a variety of mediums. Television is exemplified by SSNIT and radio is used by both NPRA and SSNIT, particu- 


\section{Utilization of Digital Literacy in Retirement Planning \\ Among Ghanaian Formal and Informal Sector Workers}

larly the trending ones. The most listened to radio stations such as Obonu FM, Vision 1 FM, Hot FM, Kasapa FM, Uniiq FM to mention but a few; outreach programs utilized by the NPRA and SSNIT ISF enables the audience to ask pertinent questions; media forums between SSNIT and media editors and/or practitioners; workshops and finally seminars. Others entail the production and distribution of brochures and informatory leaflets including reaching out to people in contexts such as churches, mosques, markets, other significant public gatherings, etc. The time slots these institutions use for public education range from 30 minutes to 2 hours. Further, the messages are propagated through the English Language, Ghanaian languages - Ga, Twi, Ewe, Dangbe. It is worth mentioning that points 2 and 4 above are indicative of digital information artifacts. The preceding discussion is skewed extremely towards non-digital artifacts to the detriment of the digital aspect. This denotes the exclusion of the large majority from technological advancement and usage in the information society.

The sensitization messages function to create structures of meanings from the life worlds of the listeners and viewers. Such messages generally invite listeners to recognize themselves as they are or might want to be. Significantly, the effectiveness and efficiency of financial education are determined by viewers and listeners. The kinds of messages put across to the populace during sensitization programs relate to the structure of the three-tier pension scheme, wherein tiers 1 and 2 are mandatory for formal sector workers tier 3 is voluntary for informal sector workers but not exclusive to them. The messages also cover a broad spectrum and come in two distinct forms namely informal and formal sector orientations. The informal sector workers information centers on the need to participate and contribute to the pension scheme, thus the opportunity to save for the future, the ability to obtain a lump sum including a monthly pension income. The messages for the formal sector workers concentrate on certain benefits that exist under tier 2 namely the use of the tier's funds to secure a primary residence.

The previous discussion projects sensitization messages in two distinct ways. First, the vagaries of retirement, for instance, its timing irrespective of which financial security assures workers the retirement they desire. Second, organizations' advice and investment instruments constitute vehicles that simplify participation in pension scheme contributions. However, some challenges were encountered in the provision of financial information such as the difficulty of explaining the composite nature of the pension system. Also, organizations consulted for permission before the sensitization campaigns often failed to respond to the requests made and/or it takes much too long for them to respond to such requests. Finally, poor attitude exhibited by the 
general public towards the information provided. The statement that 'Ghanaians do not care about the future' (Official 4) illustrates this. The provision of information in aid of retirement preparations is indicative of the socialization of workers at this level to understand the dynamics of pensions and/or retirement planning. Yet there is evidence that many individuals are not well-equipped to make sound saving decisions (Lusardi, 2008), which presupposes as Ofei-Kwapong (2013) notes that public education on the new pension scheme is 'the responsibility of the pension regulatory body, the NPRA which has done a very poor job in this regard' (p. 46).

\section{Digital and non-digital sources of retirement planning information at the individ- ual level}

The study examined the correlation between number of years of education and the need for retirement planning information. The result is a Pearson $r$ of 0.316 (31.6\%). Hence, for every change of one standard z-score unit in the number of years of education, there is one standard 0.316 standard unit of retirement planning information required in the same direction. Put differently, in predicting variations across the sample on the dependent variable, errors were reduced on all respondents by $9.98 \%$ (i.e. $\mathrm{r}^{2}$ ), by knowing information about their extent of need, all the variations that exist in the sample for need was accounted for. The number of years of education thus correlates positively with the need for retirement planning information (Table 3).

\section{Table 3 - Correlates of number of years of education and retirement planning information need}

\begin{tabular}{ccc}
\hline & $\begin{array}{c}\text { Number of years } \\
\text { of education }\end{array}$ & $\begin{array}{c}\text { Retirement planning } \\
\text { information need }\end{array}$ \\
\hline Number of years & 1 & $.316^{* *}$ \\
of education & .000 \\
& $.316^{* *}$ & 442 \\
\hline Retirement planning & .000 & 1 \\
information need & 442 & 442 \\
\hline
\end{tabular}

The result thus shows that in planning for retirement workers solicited ideas from a myriad of digital information artifacts such as the internet, tablet, including the 


\section{Utilization of Digital Literacy in Retirement Planning}

Among Ghanaian Formal and Informal Sector Workers

media - print, electronic and social (e.g., Facebook, WhatsApp, Instagram, YouTube, some books). The non-digital ones encompass books, organizations, family relations, friends. This depicts the use of hybridity of digital and non-digital spaces in obtaining new information and knowledge in relation to retirement planning (See Table 4). Table 4 shows that the formal sector respondents namely males (73\%) obtained their information from pension service providers. This suggests that informal sector workers, as well as females in general, patronize non-digital artifacts and/or resources. The males also obtained more information from bosses, insurance companies, and print media whereas the females depended more on family and own ideas. In the case of the informal sector, females depended more on their families (95.8\%), own ideas, friends, and colleagues, church. All these depict the non-digital sources of retirement planning information. This is reminiscent of technological backwardness at one level, and at another level, it may be a sign of learned helplessness regarding digital literacy diffused into the non-digital sphere. However, some of the sources were obtained from other sources such as digital sources - social media, internet, and a host of others. The digital sources of retirement planning information consist in part of books and magazines, electronic media, print media, radio, television, social media including the internet at large. This is reminiscent of the emergence of the digital age in Ghana in general and retirement planning in particular. However, it is worth acknowledging the fact that digital literacy goes beyond the dynamics of retirement planning, occupying a broader space in the life worlds of the human race. 
Table 4 - Retirement planning information sources

\begin{tabular}{lcccc}
\hline \multicolumn{1}{c}{ Information sources } & \multicolumn{2}{c}{ Formal sector } & \multicolumn{2}{c}{ Informal sector } \\
\hline & Male & Female & Male & Female \\
Family & $51.4 \%$ & $48.6 \%$ & $43.2 \%$ & $56.8 \%$ \\
Friends \& work colleagues & $61.9 \%$ & $38.1 \%$ & $41.3 \%$ & $58.7 \%$ \\
Books \& magazines & $86.4 \%$ & $13.6 \%$ & $59.1 \%$ & $40.9 \%$ \\
Experience from managing personal & & & & \\
funds & $47.2 \%$ & $52.8 \%$ & $50.0 \%$ & $50.0 \%$ \\
Financial planner & $57.1 \%$ & $52.8 \%$ & $50.0 \%$ & $50.0 \%$ \\
Pension Services Providers & $57.1 \%$ & $42.9 \%$ & $28.6 \%$ & $71.4 \%$ \\
Electronic media & $73.0 \%$ & $27.0 \%$ & $56.9 \%$ & $43.1 \%$ \\
Print media & $70.0 \%$ & $30.0 \%$ & $65.0 \%$ & $35.0 \%$ \\
Own ideas & $62.5 \%$ & $37.5 \%$ & $62.5 \%$ & $37.5 \%$ \\
Radio & $24.3 \%$ & $75.7 \%$ & $53.2 \%$ & $46.8 \%$ \\
People's experiences & $0 \%$ & $100.0 \%$ & $100.0 \%$ & $0.0 \%$ \\
Bosses & $50.0 \%$ & $50.0 \%$ & $100.0 \%$ & $0.0 \%$ \\
Church & $0.0 \%$ & $100.0 \%$ & $0.0 \%$ & $100.0 \%$ \\
Consultant & $0.0 \%$ & $100.0 \%$ & $25.0 \%$ & $75.0 \%$ \\
Banks & $100.0 \%$ & $0.0 \%$ & $100.0 \%$ & $0.0 \%$ \\
Insurance companies & $100.0 \%$ & $0.0 \%$ & $50.0 \%$ & $50.0 \%$ \\
Employers & $100.0 \%$ & $0.0 \%$ & $50.0 \%$ & $50.0 \%$ \\
Internet & $70.0 \%$ & $30.0 \%$ & $50.0 \%$ & $50.0 \%$ \\
Social media & $45.0 \%$ & $55.0 \%$ & $50.0 \%$ & $50.0 \%$ \\
Television & $27.8 \%$ & $72.2 \%$ & $33.3 \%$ & $66.7 \%$ \\
\hline
\end{tabular}

The in-depth interview data support the claims in the Table above. This amplifies the dependence on family relations as sources of retirement planning informationincluding the role of the family in the retirement planning process. Such sources like others foster great motivation to plan ahead. For example:

I got my retirement planning ideas from my daughter. She advised me to save and invest towards my old age (Informal Sector Female).

My daughter enlightened me (Informal Sector Female).

I got my retirement investment ideas from my father. My father's example challenged 


\section{Utilization of Digital Literacy in Retirement Planning Among Ghanaian Formal and Informal Sector Workers}

me. He set the pace. As a result, I refused to live with my uncle but with a friend to be challenged to achieve and acquire assets. I left a friend's house with no place to go to. But then not long after that, I bought a flat including two plots of land (Formal Sector Male).

I obtain lots of ideas from colleagues at work (Formal Sector Male).

I got counselling in relation to retirement planning at $P T C^{1}$ (Formal Sector Female).

Social media has played a significant role as my retirement planning source of information (Formal Sector Male).

My retirement planning information was mostly obtained from the internet (Formal Sector Female).

I get most of my retirement planning information from WhatsApp (Informal Sector Female).

As for me, I get most of my retirement planning information from Facebook (Informal Sector Male).

As the in-depth interview data shows, most formal organizations are in the habit of organizing seminars/workshops for workers, who are 59 years old, e.g., in Ghana Education Service, 50 years for SSNIT. The key informant interview data also show that SSNIT organizes seminars for its workers who have ten years, five years and one year to retire respectively (Official 3) the former is quite late in coming because at 59 years not much rigorous remedial measures can be instituted by workers towards a robust retirement preparation. Perhaps, serious consideration should be given to doing the same at 50 years to yield robust outcomes. Besides age segregation regarding the attendance of retirement planning seminars/workshops, including the fact that workers are often not given any counseling at work start is counterproductive.

The survey data was further subjected to Pearson Chi-square statistics and Cramer's $\mathrm{V}$ test to examine whether there is an association between retirement planning information sources and helpfulness of obtained information (Table 5). The Cramer's $5=0.705$ outcome indicates a strong existing association between the two variables.

1 PTC stands for Presbyterian Training College. 
Table 5 - Test statistics of retirement planning information sources and helpfulness

\begin{tabular}{cccc}
\hline Tests & Values & $\begin{array}{c}\text { Degrees of } \\
\text { Freedom }\end{array}$ & Asymp. Sig. (2-sided) \\
\hline $\begin{array}{c}\text { Pearson } \\
\text { Chi-Square }\end{array}$ & $438.688 \mathrm{a}$ & 10 & .000 \\
Cramer's V & 0.705 & 10 & .000 \\
N of Valid Cases & 442 & & \\
\hline
\end{tabular}

The respondents who benefitted from the digital and non-digital sources or artifacts for retirement planning information (82.4\%) drew several lessons from them, ranging from expectations about retirement, informational access, investments, savings, pension income calculation, planning for retirement, planning early (5\%), diversification of plans, 'comfortable' retirement life, retirement benefits, undertake entrepreneurship, reliance on children and social relationship building (Table 6). However, only a few of respondents (19.3) who have learned these lessons constitute a few of the respondents (17.6\%). 
Utilization of Digital Literacy in Retirement Planning

Among Ghanaian Formal and Informal Sector Workers

Table 6 - Lessons learned from retirement planning literacy

\begin{tabular}{lcc}
\hline \multicolumn{1}{c}{ Lessons } & Frequency & Percent (\%) \\
\hline Informational access & 3 & 0.70 \\
Investments \& Savings & 16 & 3.62 \\
Plan for retirement & 8 & 1.80 \\
Planning early & 14 & 3.16 \\
Diversification of plans & 22 & 4.90 \\
Pension income calculation & 1 & 0.22 \\
Expectations about retirement & 2 & 0.47 \\
Retirement & 1 & 0.22 \\
Retirement benefits & 2 & 0.47 \\
Undertake entrepreneurship & 3 & 0.70 \\
Childcare & 1 & 0.22 \\
Reliance on children & 1 & 0.22 \\
Social relationship building & 1 & 0.22 \\
Subtotal & 87 & $\mathbf{1 9 . 3}$ \\
N/A & 355 & $\mathbf{8 0 . 3}$ \\
Total & $\mathbf{4 4 2}$ & $\mathbf{1 0 0}$ \\
\hline
\end{tabular}

\section{DISCUSSION}

The retirement planning informational sources resorted to are multifaceted and consist of formal and informal pathways to information derivation. Sociologically, these are indicative of socialization involving formal and informal socialization agents. These provide different retirement planning advice and insights regarding retirement expectations, early start of retirement preparation, investments, savings, plan diversification, social networking among others. Retirement planning information facilitates positive savings attitudes which are essential in terms of resource mobilization for utilization in old age. Nonetheless, workers have diverse informational needs and saving patterns, with implications for designing, customizing and tailoring public education programs to suit the numerous needs and levels of financial knowledge. Retirement planning information and preparation towards life in old age are inseparable. 
The categorization of retirement planning information into institutional and individual worker levels connotes macro and micro level considerations. Macro, messo and micro level contexts work jointly to shape retirement planning based on partnerships centered on the mobilization and harnessing of resources, efforts, and initiatives on the part of (state) institutions and workers.

The artifacts used are suggestive of factors in their effectiveness, which may vary in different economies depending on the level of economic growth and social development. Improved retirement planning education appears to be a primary avenue for improving retirement preparation. Adzawla et al. (2015) highlight sector-specific issues in the Ghanaian economic setting indicating that:

The service providers need not handle information delivery ... as it would have been in the formal scheme because, in the case of the formal workers, the workers' contributions are deducted from source before they even get their salaries. However, the informal sector worker has to carry his/her money to the scheme's office" (p. 41).

The workers demonstrated digital literacy functioning in the following ways:

- independent engagement with learning in new (digital) contexts;

- self-selection of suitable applications for retirement planning related learning;

- autonomy in taking the lead in collaborative learning with peers and significant others.

Clarke and Svanaes (2014) articulated the essence of one-to-one access including the ability to personalize the experience of learning, which depicts capability. The workers also demonstrated meaningful utilization of digital literacy for change in the positive direction. However, their capabilities were subjected to impediments namely inadequate information access and deep-rooted perceptions. Noteworthy is that it is essential to look at the role and/or uses of digital means in relation to retirement planning as a field of digital literacy education, even at the phase of 'maturation.' Hence, following Gilster's (1997) definition, the workers have demonstrated a practical ability to use digital sources effectively.

More formal sector workers were users and/or exposed to digital artifacts and the associated digital literacy due to their nature of work. Thus, the categorization of such 


\section{Utilization of Digital Literacy in Retirement Planning Among Ghanaian Formal and Informal Sector Workers}

workers as "digitally literate" with implications for social inequality. Digital literacy has facilitated informed decision and choice making. This may have consequences for the increasing economic and social disparities in retirement preparation including education levels. Adzawla et al. (2015) found similar results regarding the latter. The positive aspects of the impact of ICT on productivity, growth and retirement planning, in particular, may cause adverse effects of increasing (economic and) social disparities in retirement preparation and thereby creating a digital divide (Hoffman, 2008). Significantly, ICT and the internet have considerable power to strengthen traditional forms of inequality based on uneven access to computer devices, and internet and level of digital literacy.

This implies that digital literacy facilitates the development of human capacity, which when improved upon may yield high gains. Because it builds competence and strengthens the associated capability to engage in the rigors of retirement preparations. From Sen's (2008) viewpoint, capability is more complicated than competence, and he reacts against models by which the well-being of groups of people is assessed upon reductionist metrics. According to Sen, capability emphasizes human diversity, the significance of choice-making (including negative choices), and the possibilities of flourishing:

The capability approach to a person's advantage is concerned with evaluating in terms of his or her actual ability to achieve various valuable functionings as a part of living ... Some functionings are very elementary, such as being adequately nourished, being in good health, and these may be strongly valued by all, for obvious reasons. Others may be more complex, but still widely valued, such as achieving self-respect or being socially integrated. Individuals may, however, differ a good deal from each other in the weights they attach to these different functionings - valuable though they may all be - and the assessment of individual and social advantages must be alive to these variations (pp. 271-272).

Competencies as functionings are utilized for a broader range of capabilities (McDougall et al., 2018) to explore the uses of particular kinds of digital technology for learning within 'a mesh of interconnections' (Livingstone \& Sefton-Green, 2016, p. 61; McDougall et al., 2018, p. 1). The potential for technology albeit digital literacy to empower and engage workers in retirement planning - digital artifacts are of shared interest among the various stakeholders and the research communities working 
across the fields of education and literacies. Subsequent technological advances, with the use of computers to design, direct and control production means human skills have been destroyed. Any digital literacy intervention that harnesses networks while making connections, both online and in 'third spaces' will need to be mindful of any deep-rooted divisions or perceptions in the local context that might impede participation (McDougall et al., 2018, p. 3). Overall, whereas the institutional level information outlines information dissemination in relation to the pension system, the individual level aspect concentrates on obtaining retirement planning information and access in general. However, they both complement each other for better outcomes. Digital literacy facilitates retirement planning information access and flows through enhanced media and other literacies and associated competencies, skills, and dispositions, while retirement planning offers the opportunities for obtaining the requisite information with implications for social inclusion.

Significantly, the worker with many capabilities could enjoy different activities; pursue different life paths including retirement planning. The functionings may be very basic for instance, being literate digitally and non-digitally. Finally, the worker as an agent is poised to be active, creative, and able to act because of their retirement aspirations.

Education albeit expressed in digital literacy has the propensity to broaden the knowledge and understanding of workers concerning pension contribution (Adzawla et al., 2015) and retirement planning in general as these workers are better informed about retirement policies as well as better placed in relation to financial management. However, there are two contrasting sets of results regarding financial education programs vis-à-vis retirement preparation. Whereas Bernheim and Garrett (2003) articulate positive financial education effect on savings and retirement plans, Duflo and Saez (200s) contend there is little or no effect of the same. Adzawla et al. (2013) reaffirm the fact that the awareness of pension schemes and the related issues, which education or digital literacy attains may prevent workers from participating in pension contribution, not to mention retirement planning in its comprehensive fashion. 


\section{CONCLUSION}

The study articulates the mundane practices of retirement planning information seeking practices of everyday life as a specific space of the agent -the worker. Noteworthy is that it speaks to the rich field of social literacies research. Retirement planning requires knowledge of tax laws, compound interest, present and future value of money and investment strategies. Such knowledge can be ascertained from digital and non-digital information means. Digital literacy tends to play a significant role in equipping workers with the necessary information, knowledge, and skills to enable proper retirement planning, and ensure financially independent retirement life. Digital, non-digital, and associated information facilitate the institution of retirement plans that may yield the following outcomes - financial security, living arrangement, social networks, healthcare, leisure/employment beyond pensions. Zaidi (2015) posits that preretirement planning facilitates increased financial security, improve health and well-being including age-friendly infrastructure. Financial security may be reflective of a regular retirement income (Adzawla et al., 2015; Dovie, 2018), whether sufficient or otherwise. Research (e.g., Snyman et al., 2017) has shown that finances are the strongest single predictor of the decision to retire and that people are more likely to leave the workforce if they can financially afford to retire than if they cannot.

Thus, the role digital literacy plays in terms of retirement planning is highly discernible. Digital literacy has become one of the key competencies to ensure social cohesion, active citizenship, and personal fulfillment (Bernsmann \& Croll, 2012, p. 53). Recognized skills and dispositions emphasis the ability of digital literacy in retirement planning through increased engagement with technological interventions. Retirement planning and the attendant prerequisite information acquisition is synonymous with human rights issues. The three defining characteristics of human rights are universality, alienability, and indivisibility. Retirement planning connotes indivisibility, a situation where retirement planning is a part of the individual worker as the worker (Borges, 2017) due to the inevitability of the retirement transition. Theoretically, the findings depict an adaptation of this study to the theoretical postulations of Atchley (2000) since in the process of retirement planning workers depend on digital and non-digital literacy to obtain information on what to do in lieu of retirement, which confirms the phenomenon of pre-retirement education as a retirement planning prerequisite. Intensification of retirement planning may be aided through greater digital literacy in the future hence salvaging the relatively invisible 
social groups like informal sector workers in the digital age. Nevertheless, this may seem unduly optimistic.

\section{REFERENCES}

Adzawla, W., Baani, S. A., \& Wontumi, R.F. (2015). Factors influencing informal sector workers' contribution to pension scheme in the Tamale Metropolis of Ghana. Asian Economic \& Social Society, 5(2), 37-45.

Agblobi, A. D. (2011). Pensions: The new instrument perspective for retirement planning. Accra: Mork Impressions.

Apperley, T., D. Jayemanne, \& B. Nansen. (2016). Postdigital Literacies: Materiality, Mobility and the Aesthetics of Recruitment. In B. Parry, C. Burnett, \& G. Merchant (Eds.), Literacy, Media, Technology: Past, Present, and Future. London: Bloomsbury.

Aral, S., Brynjolfsson, E., \& Van Alstyne, M. (2006, December). Information, technology and information worker productivity: Task level evidence. In Proceedings of the 27th Annual International Conference on Information Systems. Milwaukee, Wisconsin, USA, 9-10.

Atchley, R. C. (2000). Social forces and aging (9th ed.). Belmont, CA: Wadsworth.

Atkinson, A., \& F. Messy (2012). Measuring financial literacy: Results of the OECD / International Network on Financial Education (INFE) pilot study. OECD Working papers on finance, insurance and private pensions, No. 15, OECD Publishing.

Bernsmann, S., \& Croll, J. (2012). Lowering the threshold to libraries with social media: The approach of "Digital Literacy 2.0", a project funded in the EU Lifelong Learning Programme. Library Review, 62(1/2), 53-58. doi: $\underline{10.1108 / 00242531311328168}$

Bernheim, D., \& Garrett, D. (2003). The effects of financial education in the workplace: Evidence from a survey of households. Journal of Public Economics, 87, 1487- 1519. 
Utilization of Digital Literacy in Retirement Planning

Among Ghanaian Formal and Informal Sector Workers

Borges, G. M. (2017). Violence against women and girls as human rights violation: Creating a common language against gender-neutral concepts of abuse. Interações: Sociedade e as Novas Modernidades, 32, 5-11.

Buckingham, D. (2003). Media education: Literacy, learning and contemporary culture. Cambridge: Polity.

Burnett, C., G. Merchant, \& B. Parry, (Eds.) (2016). Literacy, media and technology: Past, present and future. London: Bloomsbury.

Bryman A. (2008). Social research methods, (3rd ed.). Oxford: Oxford University Press.

Brynjolfsson, E., \& Saunders, A. (2010). Wired for innovation: How information technology is reshaping the economy. London: The MIT Press.

Clarke, B., \& S. Svanaes. (2014). An updated literature review of the use of tablets in education. London: Tablets 4 Schools.

Creswell, J., \& Plano Clark, V. (2007). Designing and conducting mixed methods research. Thousand Oaks CA: Sage.

De-Graft Aikins, A., Kushitor, M., Sanuade, O., Dakey, S., Dovie, D., \& KwabenaAdade, J. (2016). Research on aging in Ghana from the 1950s to 2016: A bibliography and commentary. Ghana Studies Journal, 19, 173-189.

Dovie, D. A. (2018). Leveraging healthcare opportunities for improved access among Ghanaian retirees: The case of active ageing. Journal of Social Science, 7, 92. doi: $10.3390 /$ socsci7060092

Duflo, E., \& Saez, E. (2003). The role of information and social interactions in retirement Plan Decisions: Evidence from a randomized experiment. Quarterly Journal of Economics, 118, 815-842.

Gilster, P. (1997). Digital literacy. New York: John Wiley \& Sons Inc.

GSS (2014). 2010 population and housing census: District analytical report - Accra Metropolitan. Retrieved from http://www.statsghana.gov.gh/docfiles/2010_District Report/Greater\%20Accra/AMA.pdf

Hoffman, R. (2008). Socioeconomic differences in old age mortality. Dordrecht: Springer. 
Hoggart, R. (1957). The uses of literacy. London: Pelican.

Hull, G., \& J. Zacher. (2010). What is after-School worth? Developing literacy and identity out of school. Retrieved from https://www.researchgate.net/publication/242729046 What Is After-School Worth Developing_Literacy and Identity Out of School

Jenkins, H. (2011, August 11). Transmedia 202: Further reflections. [Blog Post]. Retrieved from http://henryjenkins.org/2011/08/defining transmedia further re.html

Kress, G. (2003). Literacy in the new media age. London: Routledge.

Livingstone, S., \& Sefton-Green, J. (2016). The class: Living and learning in the digital age. New York: New York University Press.

Lusardi, A., \& Mitchell, O. (2007). Financial literacy and retirement preparedness: Evidence and implications for financial education, Business Economics, 35-44.

Martin, A. (2006). Literacies for the digital age. In A. Martin \& D. Madigan (Eds.), Digital literacies for learning (pp. 3-25). London: Facet Publishing.

McDougall, J., Readman, M., \& Wilkinson, P. (2018). The uses of (digital) literacy. Journal Learning, Media and Technology, 117. doi:10.1080/17439884.2018.1462206

Messey, F. A., \& Monticone, C. (2012). The status of financial education in Africa. OECD Working paper on finance, insurance and private pensions, No. 25, OECD publishing. doi:10.1787/5k94cqqx90wl-en

Moore, D. R., \& McCabe, G.P. (1993). Introduction to the practice of statistics ( $2^{\text {nd }} \mathrm{ed}$.). New York: W.H. Freeman and Company.

Nuffield Trust (2016). Delivering the benefits of digital healthcare. Retrieved from https://www.nuffieldtrust.org.uk/files/2017-01/delivering-the-benefits-of-digital-technology-web-final.pdf

Ofei-Kwapong, N. Y. (2013). The role of Ghana's new three tier pension scheme and its effectiveness in providing social security for Ghanaians. Dissertation for Bachelor's degree in Business Administration (Unpublished dissertation). Ashesi University.

Pahl, K. (2014). Materializing literacies in communities: The uses of literacy revisited. London: Routledge. 
Utilization of Digital Literacy in Retirement Planning

Among Ghanaian Formal and Informal Sector Workers

Sen A. K. (2008). Capability and well-being. In D. M. Hausman (Ed.), The philosophy of economics, 3rd ed., (pp. 270-293). Cambridge: Cambridge University Press.

Selwyn, N. (2014). Is Technology Good for Education. London: Wiley.

Snyman, L., van der Berg-Cloete, S. E., \& White, J. G. (2017). Planning for financially independent retirement. SADJ, 72(5): $204-208$.

Street, B. (2003). What's "new" in new literacy studies? Critical approaches to literacy in theory and practice. Current Issues in Comparative Education, 5, 77-91.

Sun, W., Barboza, G. \& Richman, K. (2007). Preparing for the future: Latinos' financial literacy and retirement planning. The Business Journal of Hispanic Research, 1(2), 54-68.

Terzi, L. (2005). Beyond the dilemma of difference: The capability approach to disability and special educational needs. Journal of Philosophy of Education, 39 (3), 443-459.

Urbančíková, N., Manakova, N., \& Bielcheva, G. (2017). Socio-economic and regional factors of digital literacy related to prosperity. Quality Innovation Prosperity / Kvalita Inovácia Prosperita, 21(2). doi:10.12776/QIP.V21I2.942

Vasudevan, L., K. Rodriguez Kerr, M. Hibbert, E. Fernandez, \& Park. A. (2014). Cosmopolitan literacies of belonging in an after-school program with courtinvolved youths. Journal Socio-Economic and Regional Factors of Digital Literacy of Adolescent \& Adult Literacy, 57 (7), 538-548.

Warschauer, M., \& Matuchniak, T. (2010). New technology and digital worlds: Analyzing evidence of equity in access, use, and outcomes. Review of Research in Education, 34, 179 - 225. doi:10.3102/0091732X09349791

Worthington, A. (2005). Debt as a source of financial stress in Australian households. International Journal of Consumer Studies, 2, $201-222$.

Zaidi, A. (2015). Active aging index: A legacy of the European year 2012 for active ageing and solidarity between generations. In Policy Brief April 2015. Vienna: European Centre for Social Welfare Policy and Research. 